\title{
Granulosa Cell Tumors of the Ovary: Retrospective Analysis of 17 Cases
}

\author{
Hala Aziz Shokralla1, Ahmed Elsayed Fathalla ${ }^{2}$ \\ ${ }^{1}$ Medical Oncology Department, National Cancer Institute, Cairo, Egypt \\ ${ }^{2}$ Surgical Oncology Department, National Cancer Institute, Cairo, Egypt \\ Email: $\underline{\text { Halaaziz2001@gmail.com, drasf1975@gmail.com }}$
}

Received 17 September 2015; accepted 27 October 2015; published 30 October 2015

Copyright (C) 2015 by authors and Scientific Research Publishing Inc.

This work is licensed under the Creative Commons Attribution International License (CC BY).

http://creativecommons.org/licenses/by/4.0/

(c) (i) Open Access

\section{Abstract}

Background: Granulosa cell tumors (GCTs) are rare neoplasms with a relatively favorable prognosis. They are characterized by a prolonged history and a tendency to late recurrences. It is the most common type of sex cord-stromal tumors. Aims: To analyze, to report and to better understand the clinico-pathologic features and results of treatment, and prognostic factors of these tumors. Materials and Methods: A retrospective single-institutional review 17 cases of GCTs were treated in National Cancer Institute-Cairo University from January 2010 till December 2014. The clinical and pathological characteristics, treatment, and outcomes of patients with ovarian GCTs were analyzed. Results: Data from 17 patients were obtained. The median age was 54 years (range; 14 - 72). Abdominal pain was the most common presentation (64.7\%). The mean tumor size was $14 \mathrm{~cm}$ (range; $7-23 \mathrm{~cm})$. The majority of our patients were stage I $(\mathrm{n}=11 ; 64.7 \%)$, while $(\mathrm{n}=3$; $17.6 \%)$ had stage III and $(n=2,11.8 \%)$ were stage IV. Only one case $(5.9 \%)$ had an unknown stage (explored outside NCI). The majority of cases were of adult type disease $(n=14)$ and low grade pathology $(n=10)$. In follow-up period (median $=42$ months; ranging $9-60)$ three patients relapsed; the median overall survival time was not reached yet, however, the estimated 3-year survival was $\mathbf{7 2 . 5 \%}$. Conclusion: Granulosa cell tumors are rare neoplasms of the ovaries. They progress slowly and often are diagnosed in an early stage. Surgery is the main line of treatment. Prolonged post-therapeutic follow-up is necessary. Definition of proper prognostic factors is mandatory.

\section{Keywords}

Granulosa Cell Tumors, Ovary, Outcomes 


\section{Introduction}

Granulosa cell tumors of the ovaries are very rare malignancies. They represent the most common sex cord stromal tumors accounting for about $5 \%$ of all ovarian neoplasms [1]. They are hormone active tumors, originating from granulosa cells which produce estradiol. Overproduction of estradiol is helpful in the diagnosis of the tumor because of its numerous symptoms. These are tumors with relatively a favorable prognosis compared to epithelial ovarian cancers. Pathologically, there are two subtypes: an adult type (95\%) and a juvenile type (5\%), the latter is characterized by an early age of onset; more pronounced malignant signs and increased risk of local and systemic failure [2]. These tumors have a particular clinical and histological profile, and may reoccur up to 40 years after diagnosis [3].

Complete surgical resection either with fertility preserving procedure or not together with formal staging is the mainstay of management especially for the early stages. For advanced disease, surgery has to be combined with platinum based chemotherapeutic agents [4].

\section{Materials and Methods}

A retrospective single-institutional review of cases of ovarian granulosa cell tumors were identified from the surgical pathology files of National Cancer Institute-Cairo University from January 2009 till December 2014. The clinical and pathological characteristics, treatment, and outcomes of patients with ovarian GCTs were analyzed.

\section{Results}

\subsection{Clinical Features}

During the period from January 2009 through December 2014, 17 patients underwent surgery for granulosa cell tumors. The median age of the patients was 54 years (range: 14 - 72). About $60 \%$ of the patients, the tumor occurred between the fifth and seventh decades and ten of the patients were menopausal.

The median duration of symptomatology was 6 months (range: 5 - 23). A total of $64.7 \%$ of the patients $(\mathrm{n}=$ 11) presented abdominal pain at diagnosis followed by abdominal distension (58.8\%). Other symptomatology included vaginal bleeding either inter-menstrual (35.3\%) or postmenopausal (29.4\%) and secondary amenorrhea (12.5\%). The mean tumor size was $14 \mathrm{~cm}$ (range: 7 - $23 \mathrm{~cm}$ ).

Nulliparous patients were only $17.6 \%(\mathrm{n}=3)$. Fourteen cases were unilateral $(82.4 \%)$. As regard tumor markers; AFP, B-HCG-LDH and CA125; none was specifically raised at presentation apart of CA125 which was elevated in only five cases (37 - $56 \mathrm{U} / \mathrm{mL})$ and no recorded elevation at recurrence.

Table 1 summarizes patients' characteristics at presentation.

\subsection{Treatment}

Fourteen patients (82.4\%) underwent pan-hysterectomy with bilateral salpingo-oophorectomy, while a fertility preserving procedure (unilateral salpingo-oophorectomy and standard surgical staging) was done only in three patients. Standard surgical staging consists of peritoneal washing, peritoneal biopsies infracolic omentectomy, and any suspicious lesion biopsy.

Lymph node biopsy was done in eight patients (47.1\%), while laterality was found in three patients (17.6\%). The pathological subtype was juvenile in three patients, while the remaining was of adult type. Eleven patients had endometrial biopsies. The results were as follows: four were negative, five were hyperplastic and two were atrophic. Six patients received post-operative chemotherapy; starting from stage II disease.

In the current study all indicated cases were given BEP (bleomycin $30 \mathrm{U}$ on days 2, 9, and 16, etoposide 100 $\mathrm{mg} / \mathrm{m}^{2} /$ day on days $1-5$, and cisplatin $20 \mathrm{mg} / \mathrm{m}^{2} /$ day on days $1-5$ ) administered every 3 weeks for four courses.

Table 2 resumes different treatment modalities.

\subsection{Staging}

The staging breakdown was as follows: stage I $(64.7 \%, \mathrm{n}=11)$, stage III $(17.6 \%, \mathrm{n}=3)$ and stage IV $(11.8 \%, \mathrm{n}$ $=2)$. For the remaining patient $(n=1)$, the stage was unknown as it was explored outside NCI. 
Table 1. Patients characteristics in our study.

\begin{tabular}{lc}
\hline \multicolumn{1}{c}{ Age } & No (\%) \\
\hline$\leq 18$ years & $3(18.6 \%)$ \\
$>18$ years & $14(82.4 \%)$ \\
Symptomatology & \\
1) Abdominal pain & $11(64.7 \%)$ \\
2) Abdominal distension & $10(58.8 \%)$ \\
3) Intermenstural bleeding & $6(35.3 \%)$ \\
4) Postmenopausal bleeding & $5(29.4 \%)$ \\
5) Secondary amenorrhea & $2(12.5 \%)$ \\
Size of the tumor & \\
$\leq 14$ cm & $9(52.9 \%)$ \\
$>14$ cm & $8(47.1 \%)$ \\
Staging & \\
Stage I & $11(64.7 \%)$ \\
Stage III & $3(17.6 \%)$ \\
Stage IV & $2(11.8 \%)$ \\
Improper staging & $1(5.9 \%)$ \\
\hline
\end{tabular}

Table 2. Different treatment modalities in our study.

\begin{tabular}{cc}
\hline \multicolumn{2}{c}{ Type of surgery } \\
Fertility preserving surgery & $3(17.6 \%)$ \\
TAH + BSO & $14(82.4 \%)$ \\
Post operative & \\
Follow up only & $11(64.7 \%)$ \\
Adjuvant CTH & $6(34.3 \%)$ \\
\hline $\begin{array}{l}\text { CTH: chemotherapy; TAH + BSO: total abdominal hysterectomy \& bila- } \\
\text { teral salping-oopherctomy. }\end{array}$
\end{tabular}

\subsection{Survival}

During the follow-up (median: 42 months, ranging 9 - 60), three patients was relapsed, and one of those patients died of the disease. Four other recorded death due to either unrelated or unknown causes. The median overall 5 years survival for all cases was not reached yet. The estimated 3 year survival was $72.5 \%$ (Figure 1 and Table 3).

\section{Discussion}

Granulosa cell tumors (GCT) of the ovary are classified as sex-cord stromal tumors and their occurrence is rare, representing approximately $5 \%$ of all ovarian tumors. There are two distinct types of GCT: adult (AGCT) and juvenile (JGCT) [5] [6]. AGCTs are more common and are usually seen in peri-menopausal and post-menopausal women, with a peak incidence at 50 - 55 years. JGCTs are rare tumors, representing 5\% of all GCTs and occurring in pre-menarche girls and young women [7]. 


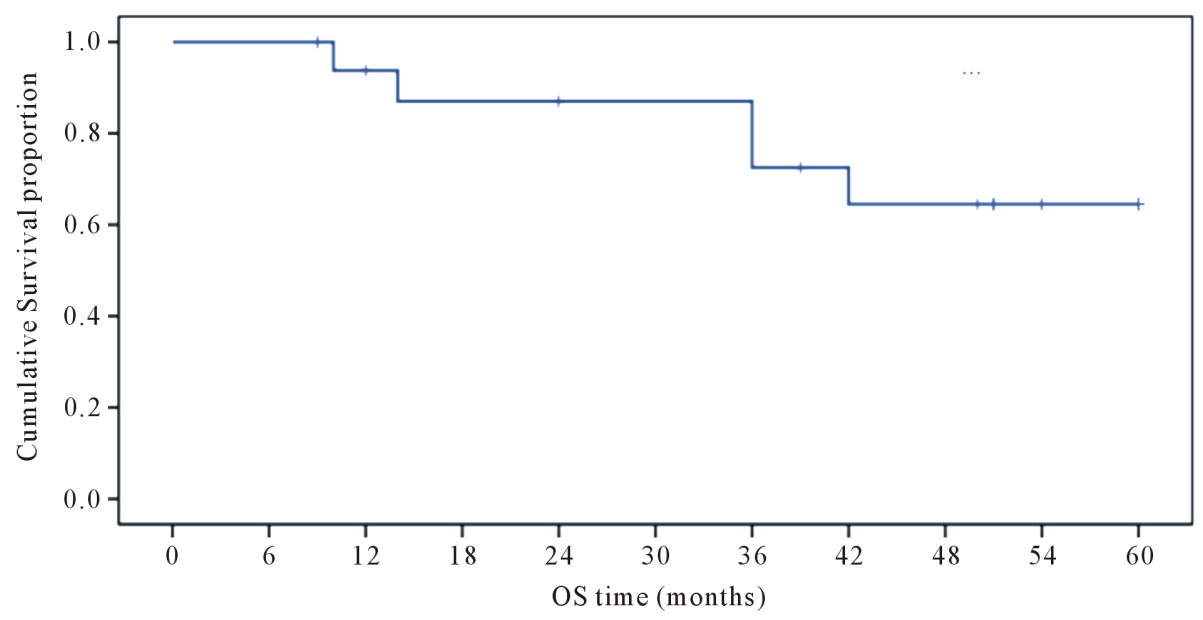

Figure 1. Overall survival of 17 cases of granulosa cell tumor.

Table 3. Shows characteristics of patients experienced recurrence.

\begin{tabular}{ccccc}
\hline Age (years) & Stage & Initial Size $(\mathrm{cm})$ & Relapse time (months) & Site of relapse \\
\hline 61 & IV & 15 & 25 & lung \\
15 & I & 12 & 49 & Retroperitoneal \\
68 & IV & 8 & 54 & Retroperitoneal \\
\hline
\end{tabular}

What makes them different from the epithelial ovarian cancers is the nature of presentation and clinical behavior. They occur in a younger age group, are usually detected in an early stage and usually have features of hyperestrogenism. They are more readily cured by surgery alone. Generally they have a better prognosis than epithelial ovarian tumors and follow an indolent course. They are characterized by a long natural history and $25 \%$ may recur years after apparent clinical cure of the primary tumor [7].

In our study the median age was 54 years old and nearly $60 \%$ of patients presented between the fifth and seventh decades. Three patients only were of the juvenile type and were younger than 18 years. These data were matching with Sekkate et al. 2013 [3] and Bompas et al. 2000 [8].

Patients may present with abdominal pain, abdominal distension related to mass effects, and hormonal events such as; menstrual irregularities, postmenopausal bleeding or amenorrhea, as reported in our patients [7] [9] [10].

Endocrinal manifestation due to estrogen secretion by the tumor may be occurring as frequent as $65 \%$ of cases. This explains the frequent association between these rare tumors and hyperplasia of the endometrium (25\% $50 \%)$ and even endometrial adenocarcinoma (5\% - 10\%). Therefore, endometrial and cervical biopsies are essential [11]-[13]. None of our patients suffered adenocarcinoma of the endometrium and five had endometrial hyperplasia.

Granulosa cell tumors usually present as a unilateral mass, with both cystic and solid components that ranges in size in most studies from $(5-40 \mathrm{~cm})$ with a mean diameter of $14 \mathrm{~cm}$ [14]-[17]. Results were matching to our work; mean size was $14 \mathrm{~cm}$ and $82.4 \%$ were unilateral.

Stromal sarcoma, endometrioid carcinoma, carcinoid tumors and adenocarcinoma are among the commonest differential diagnosis [7] [14].

The diagnosis was confirmed by immunohisto-chemistry. This tumor expresses vimentin, CD 99 and alpha inhibin markers [7] [18].

Serum CA-125 is not correlated to this tumor, instead serum estradiol, inhibin [19], Mullerian Inhibiting Substances (MIS) and anti-Mullerian hormone (AMH) are useful serum markers at diagnosis, recurrence or disease progression which may be evaluated in further studies [7].

Only five cases had raised CA125 at presentation (range: 37 - 56) and no recorded elevation at recurrence. The normal value is less than $35 \mathrm{U} / \mathrm{mL}$. Serum Ca 125 is therefore a non-specific marker [20]. 
Multi factors are determining the prognosis. The most important are stage, age, tumor size, type of surgery and tumor rupture [19]-[24]. Unfortunately; we didn’t report any due small numbers of cases to be evaluated statistically.

In the majority of publications, patients usually present early i.e. stage I disease (70\% - 90\%), thus having a very favorable outcome [7] [23] [24]. Nearly 65\% of patients in our study had stage I disease.

Complete tumor resection is the mainstay of treatment with staging for early disease and debulking for advanced disease [7] [25] [26]. There is no standard regimen concerning adjuvant treatment for granulosa cell tumors but it is usually recommended for the adult type and high risk patients. Chemotherapy typically includes a combination of platinum based chemotherapy, the most common of which is BEP regimen [7] [26] [27].

The role of adjuvant radiation therapy is still unclear. The radiation therapy dose when administrated was in the form of 50 Gy divided on 25 fractions over a period of 5 - 6 weeks [7] [17].

The median follow-up period was 42 months. $17.6 \%$ of patients suffered disease relapse which was mainly retroperitoneal. Recurrence in our patients occurred after a median period of 49 months (range; 25 - 54) in this study, which is in concordance to Mangili et al. [28]; Sehouli et al. [29] and Abu-Rustum et al. [30].

The evolution of granulosa cell tumors is slow and recurrences are rare and often delayed. These tumors can reoccur after a free interval of 6 to 23 years [7] [28]-[30].

There is a controversy regarding management of relapsed disease. Surgery may provide long-term control in localized recurrence with hyperthermic intraperitoneal chemoperfusion therapy. Distant organ failure may still need a second line therapy which is usually single agent chemotherapy or hormone therapy [31]-[33]. Radiation therapy either pelvic or whole abdominal can result in a good response in patients with persistent or recurrent disease [34].

\section{Conclusion}

Granulosa cell tumors of the ovary are rare neoplasms and have a tendency for late relapses. Several publications are still needed to set up a consensus for optimum prognostic factors, serum markers and natural behavior of the tumor.

\section{References}

[1] Karalök, A., Taşçı, T., Üreyen, I., Türkmen, O., Öçalan, R., Şahin, G., et al. (2015) Juve-Nile Granulosa Cell Ovarian Tumor: Clinicopathological Evaluation of Ten Patients. Journal of the Turkish German Gynecological Association, 16, 32-34. http://dx.doi.org/10.5152/jtgga.2015.15207

[2] Outwater, E.K., Wagner, B.J., Mannion, C., McLarney, J.K. and Kim, B. (1998) Sex Cord-Stromal and Steroid Cell Tumors of the Ovary. RadioGraphics, 18, 1523-1546. http://dx.doi.org/10.1148/radiographics.18.6.9821198

[3] Sekkate, S., Kairouani, M., Serji, B., Tazi, A., Mrabti, H., Boutayeb, S., et al. (2013) Ovarian Granulosa Cell Tumors: A Retrospective Study of 27 Cases and a Review of the Literature. World Journal of Surgical Oncology, 11, 142. http://dx.doi.org/10.1186/1477-7819-11-142

[4] Pautier, P., Lhommé, C., Culine, S., Duvillard, P., Michel, G., Bidart, J.M., et al. (1997) Adult Granulosa-Cell Tumor of The Ovary: A Rétrospective Study of 45 Cases. International Journal of Gynecological Cancer, 7, 58-65. http://dx.doi.org/10.1046/j.1525-1438.1997.00417.x

[5] Segal, R., DePetrillo, A.D. and Thomas, G. (1995) Clinical Review of Adult Granulosa Cell Tumors of the Ovary. Gynecologic Oncology, 56, 338-344. http://dx.doi.org/10.1006/gyno.1995.1060

[6] Khosla, D., Dimri, K., Pandey, A.K., Mahajan, R. and Trehan, R. (2014) Ovarian Granulosa Cell Tumor: Clinical Features, Treatment, Outcome, and Prognostic Factors. North American Journal of Medical Sciences, 6, 133-138. http://dx.doi.org/10.4103/1947-2714.128475

[7] Kottarathil, V.D., Antony, M.A., Nair, I.R. and Pavithran, K. (2013) Recent Advances in Granulosa Cell Tumor Ovary: A Review. Indian Journal of Surgical Oncology, 4, 37-47. http://dx.doi.org/10.1007/s13193-012-0201-z

[8] Bompas, E., Freyer, G., Vitrey, D. and Trillet-Lenoir, V. (2000) Granulosa Cell Tumour: Review of the Literature. Bull Cancer, 87, 709-714.

[9] Gittleman, A.M., Price, A.P., Coren, C., Akhtar, M., Donovan, V. and Katz, D.S. (2003) Juvenile Granulosa Cell Tumor. Clinical Imaging, 27, 221-224. http://dx.doi.org/10.1016/S0899-7071(02)00586-7

[10] Ugianskiene, A., Grove, A. and Soegaard-Andersen, E. (2014) Adult Granulosa Cell Tumor of the Ovary: A Retrospective Study of 37 Cases. European Journal of Gynaecological Oncology, 35, 621-624. 
[11] Fujimoto, T., Sakuragi, N., Okuyama, K., Fujino, T., Yamashita, K., Yamashiro, S., et al. (2001) Histopathological Prognostic Factors of Adult Granulosa Cell Tumors of the Ovary. Acta Obstetricia et Gynecologica Scandinavica, 80, 1069-1074. http://dx.doi.org/10.1034/j.1600-0412.2001.801120.x

[12] Uygun, K., Aydiner, A., Saip, P., Basaran, M., Tas, F., Kocak, Z., et al. (2003) Granulosa Cell Tumor of the Ovary: Retrospective Analysis of 45 Cases. American Journal of Clinical Oncology, 26, 517-521. http://dx.doi.org/10.1097/01.coc.0000037918.88451.6A

[13] Calaminus, G., Wessalowski, R., Harms, G.D. and Göbel, U. (1997) Juvenile Granulosa Cell Tumors of the Ovary in Children and Adolescents: Results from 33 Patients Registered in a Prospective Cooperative Study. Gynecologic Oncology, 65, 447-452. http://dx.doi.org/10.1006/gyno.1997.4695

[14] Stuart, G.C. and Dawson, L.M. (2003) Update on Granulosa Cell Tumors of the Ovary. Current Opinion in Obstetrics and Gynecology, 15, 33-37. http://dx.doi.org/10.1097/00001703-200302000-00005

[15] Schumer, S.T. and Cannistra, S.A. (2003) Granulosa Cell Tumor of the Ovary. Journal of Clinical Oncology, 21, 11801189. http://dx.doi.org/10.1200/JCO.2003.10.019

[16] Koukourakis, G.V., Kouloulias, V.E., Zacharias, G.A., Koukourakis, M.J., Zacharias, C.P., Mystakidou, K. and Gouliamos, A. (2008) Granulosa Cell Tumor of the Ovary: Tumor Review. Integrative Cancer Therapies, 7, $204-215$. http://dx.doi.org/10.1177/1534735408322845

[17] Hauspy, J., Beiner, M., Harley, I., Rosen, B., Murphy, J., Chapman, W., et al. (2011) Role of Adjuvant Radiotherapy in Granulosa Cell Tumors of the Ovary. International Journal of Radiation Oncology*Biology*Physics, 79, 770-774. http://dx.doi.org/10.1016/j.ijrobp.2009.12.005

[18] Lee, I.H., Choi, C.H., Hong, D.G., Song, J.Y., Kim, Y.J., Kim, K.T., et al. (2011) Clinicopathologic Characteristics of Granulosa Cell Tumors of the Ovary: A Multicenter Retrospective Study. Journal of Gynecologic Oncology, 22, 188195. http://dx.doi.org/10.3802/jgo.2011.22.3.188

[19] Lyubimova, N.V., Beyshembaev, A.M., Kushlinskiy, D.N., Zordania, K.I. and Adamyan, L.V. (2011) Granulosa Cell Tumors of the Ovary and Inhibin B. Bulletin of Experimental Biology and Medicine, 150, 635-638. http://dx.doi.org/10.1007/s10517-011-1209-z

[20] Bryk, S., Färkkilä, A., Bützow, R., Leminen, A., Heikinheimo, M., Anttonen, M., et al. (2015) Clinical Characteristics and Survival of Patients with an Adult-Type Ovarian Granulosa Cell Tumor: A 56-Year Single-Center Experience. International Journal of Gynecological Cancer, 25, 33-41. http://dx.doi.org/10.1097/IGC.0000000000000304

[21] Zhang, M., Cheung, M.K., Shin, J.Y., Kapp, D.S., Husain, A., Teng, N.N., et al. (2007) Prognostic Factors Responsible for Survival in Sex Cord Stromal Tumors of the Ovary: An Analysis of 376 Women. Gynecologic Oncology, 104, 396-400. http://dx.doi.org/10.1016/j.ygyno.2006.08.032

[22] Wu, L., Zhang, W. and Li, L. (2000) Prognostic Factors in Granulosa Cell Tumor of the Ovary. Chinese Journal of Obstetrics and Gynecology, 35, 673-676.

[23] Ayhan, A., Salman, M.C., Velipasaoglu, M., Sakinci, M. and Yuce, K. (2009) Prognostic Factors in Adult Granulosa Cell Tumors of the Ovary: A Retrospective Analysis of 80 Cases. Journal of Gynecologic Oncology, 20, 158-163. http://dx.doi.org/10.3802/jgo.2009.20.3.158

[24] Ranganath, R., Sridevi, V., Shirleyy, S.S. and Shantha, V. (2008) Clinical and Pathologic Prognostic Factors in Adult Granulosa Cell Tumors of the Ovary. International Journal of Gynecological Cancer, 18, 929-933. http://dx.doi.org/10.1111/j.1525-1438.2007.01154.X

[25] Park, J.Y., Jin, K.L., Kim, D.Y., Kim, J.H., Kim, Y.M., Kim, K.R., Kim, Y.T. and Nam, J.H. (2012) Surgical Staging and Adjuvant Chemotherapy in the Management of Patients with Adult Granulosa Cell Tumors of the Ovary. Gynecologic Oncology, 125, 80-86. http://dx.doi.org/10.1016/j.ygyno.2011.12.442

[26] Colombo, N., Parma, G., Zanagnolo, V. and Insinga, A. (2007) Management of Ovarian Stromal Cell Tumors. Journal of Clinical Oncology, 25, 2944-2951. http://dx.doi.org/10.1200/JCO.2007.11.1005

[27] Koukourakis, G.V., Kouloulias, V.E., Koukourakis, M.J., Zacharias, G.A., Papadimitriou, C., Mystakidou, K., et al. (2008) Granulosa Cell Tumor of the Ovary: Tumor Review. Integrative Cancer Therapies, 7, 204-215. http://dx.doi.org/10.1177/1534735408322845

[28] Mangili, G., Ottolina, J., Gadducci, A., Giorda, G., Breda, E., Savarese, A., et al. (2013) Long-Term Follow-Up Is Crucial after Treatment for Granulosa Cell Tumors of the Ovary. British Journal of Cancer, 109, 29-34. http://dx.doi.org/10.1038/bjc.2013.241

[29] Sehouli, J., Drescher, F.S., Mustea, A., Elling, D., Friedmann, W., Kühn, W., et al. (2004) Granulosa Cell Tumor of the Ovary: 10 Years Follow-Up Data of 65 Patients. Anticancer Research, 24, 1223-1229.

[30] Abu-Rustum, N.R., Restivo, A., Ivy, J., Soslow, R., Sabbatini, P., Sonoda, Y., et al. (2006) Retroperitoneal Nodal Metastasis in Primary and Recurrent Granulosa Cell Tumors of the Ovary. Gynecologic Oncology, 103, 31-34. http://dx.doi.org/10.1016/j.ygyno.2006.01.050 
[31] Hardy, R.D., Bell, J.G., Nicely, C.J. and Reid, G.C. (2005) Hormonal Treatment of a Recurrent Granulosa Cell Tumor of the Ovary: Case Report and Review of the Literature. Gynecologic Oncology, 96, 865-869. http://dx.doi.org/10.1016/j.ygyno.2004.10.042

[32] Briasoulis, E., Karavasilis, V. and Pavlidis, N. (1997) Megestrol Activity in Recurrent Adult Type Granulosa Cell Tumour of the Ovary. Annals of Oncology, 8, 811-812. http://dx.doi.org/10.1023/A:1008218720561

[33] Martikainen, H., Penttinen, J., Huhtaniemi, I. and Kauppila, A. (1989) Gonadotropin Releasing Hormone Agonist Analog Therapy Effective in Ovarian Granulosa Cell Malignancy. Gynecologic Oncology, 35, 406-408. http://dx.doi.org/10.1016/0090-8258(89)90089-9

[34] Hirakawa, M., Nagai, Y., Yagi, C., Nashiro, T., Inamine, M. and Aoki, A. (2008) Recurrent Juvenile Granulosa Cell Tumor of the Ovary Managed by Palliative Radiotherapy. International Journal of Gynecological Cancer, 18, 913-915. http://dx.doi.org/10.1111/j.1525-1438.2007.01133.x 